\title{
Aspectos controvertidos no uso da prova digital no ordenamento jurídico brasileiro
}

\section{Controversial aspects in the use of the digital evidence in the Brazilian Legal System}

\author{
Marco Antonio Lima Berberi* \\ Centro Universitário Autônomo do Brasil (Curitiba, Paraná, Brasil) \\ marcoberberi@unibrasil.com.br \\ https://orcid.org/0000-0002-5132-6452
}

\begin{abstract}
Bruna de Oliveira Cordeiro Hanthorne ${ }^{\star \star}$
Universidade Federal do Paraná (Curitiba, Paraná, Brasil) bruna_oliveiracordeiro@hotmail.com https://orcid.org/0000-0002-8577-6646
\end{abstract}

Recebido/Received: 02.06.2021/ June $2^{\text {nd }}, 2021$

Aprovado/Approved: 19.08.2021/ August 19th 2021

Resumo: A prova digital é o objeto em análise da pesquisa. O objetivo do trabalho de investigação é levantar os principais aspectos contraditórios concernentes à utilização da prova digital em relação à prova e aos meios probatórios tradicionais. Desenvolve-se em três principais etapas: (i) a primeira trata de analisar o objeto mediante metodologia teórico-dogmática com realização de levantamento

Como citar este artigo/How to cite this article: BERBERI, Marco Antonio Lima; HANTHORNE, Bruna de Oliveira Cordeiro. Aspectos controvertidos no uso da prova digital no ordenamento jurídico brasileiro. International Journal of Digital Law, Belo Horizonte, ano 2, n. 2, p. 137-165, maio/ago. 2021. DOI: 10.5380/IJDL. berberi.v.2.n.2

* Doutor e Mestre em Direito pela Universidade Federal do Paraná. Professor no programa de Mestrado e Doutorado do Centro Universitário Autônomo do Brasil (Curitiba, Paraná, Brasil). Especialista pelo Instituto Brasileiro de Estudos Jurídicos - IBEJ. Bacharel em Direito na UFPR. E-mail: marcoberberi@unibrasil.com.br

** Doutoranda em Direito pela Universidade Federal do Paraná (Curitiba, Paraná, Brasil). Mestra em Direito Constitucional pelo Centro Universitário Autônomo do Brasil - UNIBRASIL. Especialista em Direito Processual Civil pela Academia Brasileira de Direito Constitucional. Integrante do Instituto Brasileiro de Direito Processual. Professora da Faculdade de Pinhais - FAPI, do Centro Universitário Internacional - UNINTER, da Pontifícia Universidade Católica do Paraná - PUCPR e da UNIFAE - FAE Centro Universitário. E-mail: bruna_oliveiracordeiro@hotmail.com 
sistemático qualitativo de doutrina, na perspectiva dedutiva para delimitação conceitual, caracterização probatória e natureza de prova e prova digital; (ii) a segunda etapa recebe características empíricas na observância da regra e da efetiva prática judicial, o ensaio compara a normalização da lei com a realização prática, percebendo discrepâncias entre regra válida e jurisprudência efetivada, o experimento possibilita perceber como ocorre a admissibilidade da prova digital, recebe os atributos de autenticidade, integridade e confiabilidade; (iii) a terceira etapa une as duas anteriores habilitando elencar aspectos controvertidos da prova digital, neste estudo delimitando-se na área do direito processual civil. Conclui demonstrando alguns casos que indicam a existência de fragilidades teóricas, necessidade de aprimoramento das normas e a utilização prática que indica descompasso entre a validade e a efetividade da norma quando trata da utilização das provas no âmbito do direito digital.

Palavras-chave: Conceito de prova. Meios probatórios da prova. Natureza jurídica da Prova digital. Admissibilidade de provas. Utilização controversa da prova digital.

\begin{abstract}
The digital proof is the object under analysis and the objective of the research is to raise the main contradictory aspects concerning the use of digital evidence in relation to traditional evidence. Develops in three stages: first, it analyzes the object through dogmatic theoretical methodology with the systematic qualitative survey of doctrine in a deductive perspective for conceptual delimitation, evidential characterization and nature of proof and digital proof; the second receives empirical characteristics in the observance of the rule and effective judicial practice, the essay compares the normalization of the law with the practical realization, noticing discrepancies between valid rule and effective jurisprudence, the experiment makes it possible to perceive how the admissibility of digital evidence occurs, receives the attributes of authenticity, integrity, and reliability; the third stage joins the two previous ones, enabling to list controversial aspects of the digital evidence, in this study delimiting itself in the area of civil procedural. Concludes by demonstrating some cases that indicate the existence of theoretical weaknesses, the need to improve standards, and the practical use that indicates a mismatch between the validity and effectiveness of the standard when it comes to the use of evidence in the context of digital law.
\end{abstract}

Keywords: Concept of proof. Evidentiary means of proof. Legal nature of digital evidence. Admissibility of evidence. Controversial use of digital proof.

Sumário: 1 Introdução - 20 direito constitucional à prova no Estado Democrático de Direito - $\mathbf{3}$ Conceito de prova e meios probatórios - $\mathbf{4}$ Conceito e natureza jurídica da prova digital - $\mathbf{5}$ Admissibilidade da prova digital: autenticidade, integridade e confiabilidade - $\mathbf{6}$ Prova digital na prática jurídica e aspectos controvertidos no processo civil - 7 Considerações finais - Referências

\title{
1 Introdução
}

Um processo cooperativo pressupõe um sistema que forneça ao seu cidadão todos os meios legítimos e possíveis, para a busca e/ou satisfação do direito que pretende atingir. E para que a parte exerça de forma plena, o exercício potestativo de seu direito, é necessário que tenha a oportunidade de demonstrar a sua causa de pedir, por meio de provas legais e legítimas, ainda que não expressamente determinadas em lei. É neste contexto que se inserem as provas digitais. $O$ direito fundamental à prova encontra-se previsto na Constituição da República Federativa do Brasil de 1988 (doravante sigla CF/88) por meio do artigo 5ํ, incisos XXXV, LIV e LVI. A partir do artigo 369 do Código de Processo Civil brasileiro de 2015 - Lei no 13.105, de 16 de março de 2015 (doravante CPC/15) serve ao mesmo propósito da $\mathrm{CF} / 88$. Descreve que a parte poderá utilizar inesgotavelmente todos os meios legais 
e moralmente legítimos, possibilitando que se faça a comprovação salvaguardando a do seu direito, para além dos previamente estipulados em lei.

Ocorre que com o contínuo avanço da tecnologia, das diversidades de formas e de aumento significativo de espaço para armazenamento de dados, os meios de comprovação dos fatos também estão se modificando. Especialmente após a pandemia da Covid-19 o uso de recursos tecnológicos de comunicação e armazenamento de dados acelerou demasiadamente. A utilização de recursos digitais e o armazenamento de dados na rede por meio de diversas tecnologias registram a maioria das ações que são tomadas na vida; de modo crescente cada vez mais o cotidiano está documentado: é o som do que se fala que o celular grava, além da imagem que pode captar por vídeo ou foto, do mesmo modo o computador da sua mesa, o tablet, o notebook, a câmera da vigilância são só alguns exemplos do que aparelhos com inteligência artificial podem fazer e fazem, de modo não autorizado. Além disso, atualmente já é hábito, mania ou cultura postar e compartilhar com o público absolutamente tudo que se faça.

Todas as experiências precisam ser registradas em mais de uma rede social. Muitos dados gerados, mesmo que apagados do aparelho ou deletados do software, ficam na memória do aparelho celular ou armazenados na nuvem. Desde o pedido de um lanche por aplicativo, até a intimação de partes em processo judicial, mesmo que em criptograma. Pode não ser possível o acesso e ler agora por causa da codificação. Mas se trata do agora momentâneo, neste ano, mas armazenado e gravado de modo que não seja possível apagar por vias normais, no futuro poderemos acessar e ler tudo que ali está e ficará.

Diante das inovações e mudanças que não há pessoa que consiga acompanhar, quem dirá a regulação que poderia dar certa segurança jurídica... Impossível acompanhar, o mundo digital possui dinâmica com aceleração crescente; assim cada vez mais longe do mundo concreto se apresenta. Aquela que se mostra mais presente é a adjetivada como virtual, digital e informatizada. Ao mesmo tempo, só carrega dados agregando mais informações e complexidade, acarretando em uma insegurança que assombra. 0 artigo atenta-se em abordar o microcosmo desta nova dimensão da existência humana que se projeta no universo digital. Como ser, estar, provar no novo e recém-descoberto universo digital, quais seriam os aspectos controvertidos na utilização de uma prova que sendo digital, poderia ser real e substancialmente aceita? Poderia ser material e concretamente irrefutável? Como as regras jurídicas conseguem dar ordem e segurança jurídica ao brasileiro?

Por conta dos aspectos inerentes à complexidade do tema, a metodologia pautase em técnicas retilíneas de investigação, descrição, conceituação e apresentação do relatório de estudo em forma de artigo. Desde modo, a especificação do tema está enunciado como utilizado a prova digital, entendida como aquela armazenada em 
recursos tecnológicos, podendo ser em mini $\left[10^{-3}\right]$, micro $\left[10^{-6}\right]$, nano $\left[10^{-9}\right]$, pico $\left[10^{-12}\right]$ dados. É codificação tratada de dados com "uma sequência de números binários (isto é, zero ou um) que, reconhecidos e traduzidos pelo computador, representam uma informação", ${ }^{1}$ ou ainda, como aquela que se utiliza do meio eletrônico para a formação da própria prova digital, uma vez que arquivos produzidos em computador, banco de dados, editor de texto ou qualquer outra forma de programação, podem ser utilizados para a constatação de fatos jurídicos.

Metodologicamente, o texto inicialmente trata de termos do direito digital compreendido como um conjunto básico de conteúdos relacionados à prova e ao direito constitucional. A lógica é de que o estudo habilite o indivíduo e possibilite trazer elementos para a construção de uma decisão judicial motivada e a relação da prova digital. Na sequência, o estudo pauta-se na verificação dos elementos analíticos da validação do conceito e dos meios probatórios. Tal fato deverá ser formalmente realizado e somente assim há espaço para a adoção da admissibilidade de provas digitais prescrita no ordenamento jurídico brasileiro.

Partindo desses pressupostos, buscar-se-á compreender o instituto das provas digitais, seu conceito e sua natureza jurídica. Em sequência, buscar-se-á compreender os critérios de sua admissibilidade: autenticidade, integridade e confiabilidade. De posse destas informações, passar-se-á ao principal objetivo deste artigo: a análise dos aspectos controvertidos da utilização da prova digital no ordenamento jurídico brasileiro, com a observância de casos práticos já julgados pelos Tribunais Superiores. O presente artigo não pretende esgotar o tema, mas sim trazer reflexões acerca dos avanços da utilização da prova digital no exercício do acesso à justiça, em um processo cooperativo.

\section{O direito constitucional à prova no Estado Democrático de Direito}

O direito à prova é garantido pela CF/88 por meio do artigo 5으, incisos XXXV, LIV e LVI, bem como pelo CPC/15, por meio do artigo 369. 0 direito fundamental à prova tem origem nas garantias do justo processo, por meio dos princípios do contraditório e ampla defesa, resultando em verdadeira “liberdade de acesso às fontes e aos meios segundo o disposto em lei e sem restrições que maculem o justo processo". ${ }^{2}$

LESSA, Breno Munici. A invalidade das provas digitais no processo judiciário. Mar. 2010. Disponível em: http://jus.uol.com.br/revista/texto/14555/a-invalidade-das-provas-digitais-no-processo-judiciario/print. Acesso em: 28 fev. 2021.

2 AMARAL, Paulo Osternack. Provas: atipicidade, liberdade e instrumentalidade. $2^{a}$ ed. São Paulo: Revista dos Tribunais, 2020. 
Assim como o direito constitucional de acesso à justiça, o que é importante ressaltar é a necessidade da efetividade do direito ao acesso à Justiça. O que implica em "ser processado, julgado e sentenciado pela autoridade competente, dentro do processo legal e com a ampla defesa garantida". ${ }^{3} 0$ direito fundamental à prova insere-se como "direito subjetivo de provar no processo os fatos que emergem as pretensões ou exceções das partes". ${ }^{4}$ Adotar o direito à prova em sua seara constitucional é constatar que a sua utilização deverá ser concedida pelo julgador em seu amplo espectro, de modo a contribuir para a prolação de uma decisão fundamentada, nos termos do art. 371 do CPC/15, com a admissão de todas as provas idôneas, ainda que não previstas expressamente em lei - art. 369 -, bem como indicar a necessidade da produção de determinadas provas, examinando-as criticamente, em atenção ao dever de cooperação das partes com o julgador.

Para o juiz, que representa o Estado em face do jurisdicionado, cabe a prestação de um serviço jurisdicional em sua função social, conforme artigo 8응 do $\mathrm{CPC} / 15$, ao dispor que: “Ao aplicar o ordenamento jurídico, o juiz atenderá aos fins sociais e às exigências do bem comum, resguardando e promovendo a dignidade da pessoa humana e observando a proporcionalidade, a razoabilidade, a legalidade, a publicidade e a eficiência". ${ }^{5}$ Trata-se de compreender que a jurisdição não se presta apenas a "dizer o direito" ou a "satisfazer os interesses pessoais dos jurisdicionados", mas deve ir além, de modo que "a exigência de aplicação do ordenamento jurídico de acordo com fins sociais e com as exigências do bem comum não pode significar outra coisa senão aplicação do ordenamento jurídico processual, sem o desvirtuamento de sua função". ${ }^{6}$

De outro lado, o direito fundamental à prova sob o viés das partes, se traduz na possibilidade de que estas venham a utilizar todas as provas compatíveis e idôneas existentes, expressas ou não, para a comprovação de suas alegações, bem como o direito de que possam se insurgir quanto às provas produzidas, em todas as fases do processo, influenciando diretamente a atividade probatória do juiz. Compatibilizar o direito à prova em seu viés constitucional é lhe conferir um "feixe de garantias constitucionais que de um lado, asseguram às partes o exercício de suas faculdades e poderes processuais e, do outro, são indispensáveis ao correto exercício da jurisdição" que buscam "salvaguarda do próprio processo".7

AMARAL, Paulo Osternack. Provas: atipicidade, liberdade e instrumentalidade. $2^{\mathrm{a}}$ ed. São Paulo: Revista dos Tribunais, 2020.

4 AMARAL, Paulo Osternack. Provas: atipicidade, liberdade e instrumentalidade. $2^{\text {a }}$ ed. São Paulo: Revista dos Tribunais, 2020.

5 CAPONI, Remo. O princípio da proporcionalidade na justiça civil: primeiras notas sistemáticas. Tradução: Sérgio Cruz Arenhart. Revista de Processo, v. 192, ano 36, p. 400-401, São Paulo: RT, fev. 2011.

6 MARINONI, Luiz Guilherme; ARENHART, Sérgio Cruz; MITIDIERO, Daniel. Novo CPC/15 comentado. São Paulo: Revista dos Tribunais, 2015, p. 105.

7 A este respeito, STJ: “(...) 2. A observância desses preceitos, longe de apego excessivo a formalismo, na verdade resguarda o devido processo legal e assegura o direito pleno de defesa, com possibilidade ampla de produção de provas, pois o processo cautelar, com nítido escopo de garantia e acessoriedade, tem por 
Em um sistema neoconstitucional, não há como se admitir uma norma totalmente absoluta, inflexível, posto que “incide em grave erro metodológico quem pretende construir, por via dedutiva, a partir de qualquer princípio, ou quaisquer princípios, um sistema processual completo e fechado, que fosse desdobramento de um rígido encadeamento lógico, até as últimas consequências". ${ }^{8}$ Se a sociedade se desenvolve gradativamente em vários setores, em especial, da tecnologia, o direito também deve acompanhar este caminho, sob pena de se tornar obsoleto e ineficaz É constatar, com amparo constitucional, uma amplitude probatória expressa na legislação, e de que a admissão da prova digital, é expressão concreta. ${ }^{9}$

\section{Conceito de prova e meios probatórios}

A etimologia do vocábulo "prova" advém da palavra latim proba, verbo probare, definida como aquele que serve para estabelecer uma verdade por verificação ou demonstração. ${ }^{10} \mathrm{~A}$ prova não é assunto exclusivamente tratado pelo direito processual, mas também é utilizada pela filosofia, sociologia e pela epistemologia, em sua forma mais natural, ${ }^{11}$ não obstante se apresente no direito processual de maneira singular, com regramentos específicos. A definição de prova, como consequência, dependerá do campo de conhecimento que se pretende atingir. $A$ prova pode significar os meios e instrumentos que se utiliza o magistrado para o conhecimento dos fatos submetidos à sua análise, por intermédio das provas expressa em lei - prova documental, pericial, testemunhal e documental. Também pode se conjecturar como o procedimento por meio do qual a cognição se forma e é recepcionada em juízo, pela produção da prova em si. Mais ainda, a prova pode significar a atividade lógica para o juiz, para a percepção dos fatos (seja pela epistemologia, dedução, indução, percepção). ${ }^{12}$ E por fim, a prova pode ser vista como o resultado de uma atividade lógica do juiz, tendente ou não, a buscar a "verdade dos fatos", na visão de Michele Taruffo e Enrico Liebman. ${ }^{13}$

finalidade apenas assegurar a eficácia do provimento a ser proferido na demanda principal. (...)” (BRASIL. STJ. REsp 540.042/CE, Rel. Ministro Luis Felipe Salomão, Quarta Turma, julgado em 10/08/2010, DJe_24/08/2010. Disponível_em:_https://ww2.stj.jus.br/revistaeletronica/Abre_Documento.asp?sSeq $=992628 \&$ sReg=200300286280\&sData=20100824\&formato=PDF. Acesso em: 13 ago. 2020).

8 MOREIRA, José Carlos Barbosa. A garantia do contraditório na atividade de instrução. Revista de Processo, São Paulo, v. 35, p. 283, 1984.

9 AMARAL, Paulo Osternack. Provas: atipicidade, liberdade e instrumentalidade. 2ª ed. São Paulo: Revista dos Tribunais, 2020.

10 MICHAELIS. Moderno Dicionário da Língua Portuguesa. Disponível em: https://michaelis.uol.com.br/ moderno-portugues/busca/portugues-brasileiro/prova/. Acesso em: 30 set. 2019.

11 Extensamente: HAACK, Susan. Evidence matters: science, proof, and truth in the law. Cambridge University Press, 2014.

12 MARINONI, Luiz Guilherme; ARENHART, Sergio Cruz; MITIDIERO, Daniel. Novo curso de processo civil: tutela dos direitos mediante procedimento comum. V. 2. São Paulo: Revista dos Tribunais, 2015, p. 249.

13 Nessa mesma linha, trilha o pensamento de Neves e Castro e Pontes de Miranda, que sustentam que “podemos definir as provas no seu sentido lato: - o meio pelo qual a intelligencia chega à descoberta da verdade. No seu sentido jurídico, porém, define-as a nossa lei civil - a demonstração da verdade dos 
A compreensão da prova em seu campo jurídico, objetivo do presente estudo, segundo Giovanni Verde, se perfaz na ampla liberdade de convencimento em que se baseia o exercício da atividade jurisdicional, em que "todos aqueles instrumentos na base dos quais se pode fixar a hipótese à qual a norma torna possível implicar os efeitos jurídicos pretendidos". ${ }^{14}$ Neste viés, a prova perpassa por três perspectivas distintas: atividade, meio e resultado. A prova como atividade, também conhecida em seu aspecto subjetivo, infere-se do resultado que advém as partes ou o juiz. ${ }^{15}$ Traduz-se como aquela que possui natureza processual, e não material, e que possui um "aspecto essencial da atividade desenvolvida pelo órgão jurisdicional, a fim de ele cumprir sua função". ${ }^{16}$

A prova como meio, em seu âmbito objetivo, revela-se como o ato de provar por um determinado meio de prova (documental, pericial, testemunha). ${ }^{17}$ As provas em um processo se constituem caminhar por meio dos fatos para chegar primeiro, aos sentidos humanos, depois ao julgamento na mente do juiz (nihil est in intellectu quod nonfuerir in sensu). ${ }^{18}$ Significa mostrar a todos e com o juiz poder proporcionar indícios da verdade sobre os conhecimentos que subsidiam o juiz na tomada de decisão, fato que resulta na reconstituição mentalmente de fatos relevantes para a composição do conflito e extinção do litígio. A prova se traduz em uma verdade substancial, que se conceitua como "elemento de confirmación de conclusiones referidas a aserciones sobre hechos o bien como premisa de inferencias dirigidas a fundamentar conclusiones consistentes en aserciones sobre hechos" ${ }^{19}$ Então surge a função do processo: "conhecer (cognoscere); e essa é a matriz legitimante de toda atividade jurisdicional". ${ }^{20}$

Assim, necessário saber é que o trabalho, é união do homo mais a res, sendo que esta coisa sabe-se que está em volta de um homo: que o homo iudicans trabalhe sobre o homo iudicandus constitui, unir-se com ele como um dever; somente por

factos allegados em juizo" (CASTRO, Francisco Augusto das Neves e; PONTES DE MIRANDA, Francisco Cavalcanti. Theoria das provas e sua applicação aos actos civis, p. 14 (grafia original). TARUFFO, Michele et al. La prova..., p. 72-73; TARUFFO, Michele. Prove atipiche e convencimento del giudice. Rivista di Diritto Processuale, Padova, a. 28, n. 3, p. 389-395, jul./set. 1973.

14 VERDE, Giovanni. La prova nel processo civile (Profili di teoria generale). Rivista di Diritto Processuale. Padova. CEDAM, 1998, p. 590.

15 DIDIER JR., Fredie; BRAGA, Paula Sarno. Carta psicografada como fonte de prova no processo civil. Revista de Pós-Graduação da Universidade da Bahia, 2013, v. 25, p. 193.

16 WAMBIER, Luiz Rodrigues; TALAMINI, Eduardo. Curso avançado de processo civil. V. 2: cognição jurisdicional: processo comum de conhecimento e tutela provisória. 16ª ed., rev., atual. e ampl. São Paulo: Revista dos Tribunais, 2016, p. 225.

17 DIDIER JR., Fredie; BRAGA, Paula Sarno. Carta psicografada como fonte de prova no processo civil. Revista de Pós-Graduação da Universidade da Bahia, 2013, v. 25, p. 193.

18 MOREIRA, José Carlos Barbosa. Provas atípicas. Revista de Processo, São Paulo: RT, v. 19, n. 76, 1994, p. 115.

19 TARUFFO, Michele. La prueba de los hechos. Madrid: Trotta, 2002, p. 327.

20 MARINONI, Luiz Guilherme; ARENHART, Sérgio Cruz. Prova e Convicção. 5a ed., rev., atual. e ampl. São Paulo: Revista dos Tribunais, 2019, p. 29. 
meio da fusão poderá saber como puderam se passar as coisas (come somo le cose) e como deveriam ser, a sua trajetória e a sua estima; em suma uma palavra que pode definir é a sua verdade. ${ }^{21}$ No que concerne às partes, Liebman, entende que “a prova é o instrumento de que se valem as partes para demonstrar as alegações fáticas que embasam suas pretensões de tutela jurisdicional ou suas defesas em face de tais pretensões". ${ }^{22}$ Assim, entender a prova como resultado pressupõe o seu conteúdo, com a utilização dos diversos meios de prova compatíveis em lei e/ ou idôneos, ainda que não expressamente indicados em legislação.

Se os meios probatórios são instrumentos de aquisição de provas, nos trâmites processuais e procedimentos, as provas são resultantes alcançadas após a concretização desse serviço de transferência. ${ }^{23} \mathrm{~A}$ análise e consequência jurídica, como reflexo, é a extração dos resultados probatórios, ou seja, “aparelho de que se valem as partes para confirmar as argumentações dos fatos experimentados que fundamentam suas ambições de tutela jurisdicional ou suas defesas em face de tais anseios". ${ }^{24}$ Trata-se de assuntos de passagem "entre as outras pessoas ou coisas até mesmo fenômenos, de um lado, e a razão do juiz, de outro". ${ }^{25}$ Deste modo o esforço da empreitada analítica está focado na prova como meio, isto é, como pontos que não precisam necessariamente estarem expressos e tipificados em lei. E isto porque, de acordo com o art. 5으. LVI da CF/88, juntamente com o art. 369 do CPC/15, o ordenamento jurídico brasileiro admite quaisquer tipos de prova - tanto típicos, quanto atípicos - mas desde que sejam idôneas e legítimas. ${ }^{26}$

\section{Conceito e natureza jurídica da prova digital}

A Lei no 9.800/99 foi a primeira que passou a regulamentar a evolução tecnológica no Judiciário, com a possibilidade de apresentação de documentos e, até mesmo, a interposição de recursos, via fac-símile. Contudo, ao enviar o documento por este meio, a parte era obrigada a apresentar o físico, em momento posterior. Ou seja, não se tratava de uma prova digital, propriamente dita, mas sim, de “documentos que se prestam à transmissão de informações por meio de redes

21 CARNELUTTI, Francesco. Diritto e processo. Napoli: Morano, 1958, p. 124.

22 LIEBMAN, Enrico Túlio. Manual de direito processual civil. Tradução: Cândido R. Dinamarco. Rio de Janeiro: Forense, 1984, v. 1, p. 226.

23 THAMAY, Rennan; TAMER, Maurício. Provas no direito digital: conceito da prova digital: procedimentos e provas digitais em espécie. São Paulo: Thomson Reuters Brasil, 2020, p. 31

24 LIEBMAN, Enrico Túlio. Manual de direito processual civil. Tradução: Cândido R. Dinamarco. Rio de Janeiro: Forense, 1984, v. 1, p. 226.

25 MOREIRA, José Carlos Barbosa. Provas atípicas. Revista de Processo, São Paulo: RT, v. 19. n. 76, 1994, p. 118.

26 Acerca da possibilidade de admissão de provas ilícitas sob o viés do princípio da proporcionalidade, vide MARINONI, Luiz Guilherme; ARENHART, Sérgio Cruz. Prova e Convicção. 5a ed., rev., atual. e ampl. São Paulo: Revista dos Tribunais, 2019, p. 285-304. 
de comunicações". ${ }^{27}$ No Código Civil de 2002 - Lei no 10.406, de 10 de janeiro de 2002 (CC/02), os artigos 212 e 225, tratam da utilização do meio eletrônico e a reprodução de fatos ou coisas como meios de prova. No ano de 2006 foi promulgada a Lei no 11.419 , que passou a dispor da informatização do processo judicial. Representou um marco regulatório essencial para a informatização do Judiciário brasileiro. Em 2013, foi promulgada a Resolução № 185/16 do Conselho Nacional de Justiça, que passou a instituir o Sistema de Processo Judicial Eletrônico - PJE, como sistema de processamento de informações e práticas de atos processuais, tendo feito a distinção entre documento eletrônico e processo eletrônico, nos termos do art. 3o do referido diploma. ${ }^{28} \mathrm{O} \mathrm{CPC} / 15$, por sua vez, passou a elencar em artigos específicos, embora com certa timidez, sobre a prova eletrônica pelos artigos 422, §1ํㅡ e 439, 440 e 441, como documentos eletrônicos.

Na leitura do art. 493 do CPC/15, por exemplo, parece que o legislador ainda considera o suporte físico em papel como a regra geral, ao dispor que "A utilização de documentos eletrônicos no processo convencional dependerá de sua conversão à forma impressa e da verificação de sua autenticidade, na forma da lei". Ao redigir o artigo, o legislador poderia ter indicado, desde logo, a preferência aos documentos eletrônicos, em atenção aos avanços tecnológicos e à digitalização dos processos físicos. Contudo, o CPC/15 ainda se encontra enraizado aos processos físicos, o que se mostra cada vez mais afastado da realidade atual dos processos judiciais que, em sua maioria, são eletrônicos.

Parece que o legislador se preocupou com o valor probatório da prova na forma digital. Entretanto, tal análise cabe ao juiz, em atendimento ao princípio do livre convencimento motivado conforme o art. 371, bem como em análise ao art. 440 do CPC/15: “O juiz apreciará o valor probante do documento eletrônico não convertido, assegurado às partes o acesso ao seu teor". Tal posicionamento do legislador não

27 MARINONI, Luiz Guilherme; ARENHART, Sergio Cruz; MITIDIERO, Daniel. Novo curso de processo civil: tutela dos direitos mediante procedimento comum. V. 2. São Paulo: Revista dos Tribunais, 2015, p. 366.

28 Art. 3 "Para o disposto nesta Resolução, considera-se: I - assinatura digital: resumo matemático computacionalmente calculado a partir do uso de chave privada e que pode ser verificado com o uso de chave pública, estando o detentor do par de chaves certificado dentro da Infraestrutura de Chaves Públicas Brasileira (ICP-Br), na forma da legislação específica; II - autos do processo eletrônico ou autos digitais: conjunto de metadados e documentos eletrônicos correspondentes a todos os atos, termos e informações do processo; III - digitalização: processo de reprodução ou conversão de fato ou coisa, produzidos ou representados originalmente em meio não digital, para o formato digital; IV - documento digitalizado: reprodução digital de documento originalmente físico; $\mathrm{V}$ - documento digital: documento originalmente produzido em meio digital; $\mathrm{VI}$ - meio eletrônico: ambiente de armazenamento ou tráfego de informações digitais; VII - transmissão eletrônica: toda forma de comunicação à distância com a utilização de redes de comunicação, preferencialmente a rede mundial de computadores; VIII - usuários internos: magistrados e servidores do Poder Judiciário, bem como outros a que se reconhecer acesso às funcionalidades internas do sistema de processamento em meio eletrônico, tais como estagiários e prestadores de serviço; IX usuários externos: todos os demais usuários, incluídos partes, advogados, membros do Ministério Público, defensores públicos, peritos e leiloeiros". 
escapou de críticas da comunidade acadêmica de um modo geral. Neste sentido, vale ressaltar o posicionamento de Luiz Guilherme Marinoni e Sergio Cruz Arenhart:

\begin{abstract}
Estabelece o código que, se o documento não for convertido ao meio físico pode o juiz dar-lhe o valor que entender adequado, desde que assegure às partes do processo o seu teor (art. 440 do $\mathrm{CPC} / 15$ ). Novamente, um preceito sem qualquer valor. Afinal, sempre cabe ao juiz avaliação do valor probante de todas as provas, sendo também inquestionável que as partes devem ter direito de acessar as fontes de prova realizadas, até para que possam exercer o contraditório. ${ }^{29}$
\end{abstract}

Também não há como passar despercebida a análise do art. 441, que se refere aos documentos eletrônicos em lei específica, mais uma vez demonstrando certo receio do legislador ao tratar sobre as provas digitais: "Serão admitidos documentos eletrônicos produzidos e conservados com a observância da legislação específica”. Mas afinal, existe diferença entre a prova elaborada por meio eletrônico daquela que é originalmente digital? $\mathrm{O}$ que se pode chamar de prova digital? E qual a sua natureza jurídica? A resposta para estas perguntas pode ser encontrada em dois aspectos: objetivo da prova e a semântica do termo digital agregado à palavra prova.

Se o emprego da prova, de um modo geral, é o de convencer/provar determinado fato e/ou direito ao juiz, o qual, por sua vez, exerce o seu livre convencimento motivado, não há qualquer diferença na prova física ou digital, posto que ambas, em sua essência, possuem a mesma finalidade. Ambas se diferenciam, de fato, pelo seu suporte, uma vez que "enquanto a prova tradicional se dá por meio de papel ou objetos corpóreos, a prova eletrônica é constituída por meio de bits, que nada mais é do que uma unidade de informação". ${ }^{30}$ Por outro lado, ao analisar a semântica do termo digital, é possível vislumbrar dois aspectos. O primeiro, de que a prova digital pode ser entendida como "a demonstração de um fato ocorrido nos meios digitais, isto é, um fato que tenha como suporte a utilização de um meio digital”. E, em segundo, porque embora a prova não tenha origem de forma digital, "a demonstração de sua ocorrência se dá por meios digitais". ${ }^{31}$

Como provas originárias do meio digital, pode-se citar: o e-mail, o envio de mensagens por aplicativos eletrônicos: WhatsApp, Instagram, Telegram, Twitter, cópia de software e/ou de dados e/ou vídeos na internet. Também é possível que o meio digital sirva de prova para a comprovação de fato ocorrido fora do âmbito

29 MARINONI, Luiz Guilherme; ARENHART, Sérgio Cruz. Prova e Conviç̧ão. 5a ed., rev., atual. e ampl. São Paulo: Revista dos Tribunais, 2019, p. 625.

30 RAFFUL, Leonardo José; RAFFUL, Ana Cristina. Prova eletrônica. Revista do Direito Público, Londrina, v. 12, n. 2, p. 48-76, ago. 2017, p. 60. DOI: 10.5433/1980-511X.2017v12n2p48

31 THAMAY, Rennan; TAMER, Maurício. Provas no direito digital: conceito da prova digital: procedimentos e provas digitais em espécie. São Paulo: Thomson Reuters Brasil, 2020, p. 32. 
digital. Exemplo disto é a lavratura de ata notarial, pelo tabelião, de uma foto em que aparecem duas pessoas, tendo uma delas declarado em juízo que não conhecia a outra parte, para a contradita ou invalidade da oitiva de testemunha em juízo. Ou ainda, fotografias em mídias sociais que demonstram a situação econômica de uma parte, para a comprovação da possibilidade financeira ao pagamento de determinado valor, a título de alimentos.

Em observância à segunda pergunta: “o que é a prova digital?”, os aspectos até aqui analisados levam a concluir o conceito de prova digital como um "instrumento jurídico vocacionado a demonstrar a ocorrência ou não de determinado fato e suas circunstâncias, tendo ele ocorrido total ou parcialmente em meios digitais ou, se fora deles, esses sirvam como instrumento para a sua demonstração". Trata-se de compreender que a prova digital "é o meio de demonstrar a ocorrência de um fato ocorrido em meio digital, ou que tem no meio digital um instrumento de demonstração de determinado fato de seu conteúdo". ${ }^{32}$

E se a prova digital, assim como a física, visa demonstrar a ocorrência de determinado fato, na busca da comprovação do direito que a parte entende ter, constata-se, em atenção à terceira pergunta, que as provas obtidas por meios eletrônicos ou originárias destes meios, possuem a natureza de prova documental, conforme dispõe a sessão VII, Capítulo XII, do Livro I, da parte especial do CPC/15, a partir do art. 405, entretanto, com características próprias, conforme os artigos 439 a 441.

Para Humberto Theodoro Jr., a prova documental "é o resultado de uma obra humana que tenha por objetivo a fixação ou retratação material de algum acontecimento. (...) Em sentido lato, documento compreende não apenas os escritos, mas toda e qualquer coisa que transmita diretamente um registro físico a respeito de algum fato, como os desenhos, as fotografias, as gravações sonoras, filmes cinematográficos etc.". Ainda, verifica-se que a prova documental "cuida-se especificamente dos documentos escritos, que são aqueles em que o fato vem registrado pela palavra escrita, em papel ou outro material adequado". ${ }^{33}$

Também quanto à natureza jurídica da prova documental digital, necessária a distinção entre documentos de informática e de telemática. Os documentos informáticos são aqueles que se encontram inseridos em memórias de computadores, ou resultantes de cálculos por equipamentos eletrônicos, tais como: WhatsApp, Instagram, Telegram, Twitter, cópia de software e/ou de dados e ou vídeos na internet. Já os documentos telemáticos, por sua vez, são aqueles que objetivam

32 THAMAY, Rennan; TAMER, Maurício. Provas no direito digital: conceito da prova digital: procedimentos e provas digitais em espécie. São Paulo: Thomson Reuters Brasil, 2020, p. 33.

33 THEODORO JUNIOR, Humberto. Curso de direito processual civil. São Paulo: Forense, 2015. V. 1, p. 944. 
a transmissão de informações pelas redes de comunicação, como por exemplo: telex, fac-simile, telegrama, serviços de telefonia, fibra ótica, satélite, cabo etc.

Tais distinções se mostram importantes, porque as controvérsias da utilização da prova digital no ordenamento jurídico brasileiro e, em especial, no processo civil, perpassam pela origem do documento e a incerteza quanto à sua autoria. Assim, para a admissibilidade, é imprescindivel questionar quais são os critérios que devem ser observados para a sua admissibilidade no ordenamento jurídico brasileiro. É o que o próximo tópico passará a abordar.

\section{Admissibilidade da prova digital: autenticidade, integridade e confiabilidade}

Para que haja a admissibilidade da prova digital em um processo judicial é necessário que se observem três fatores, os quais devem estar presentes para a utilização da prova de forma válida. Caso não ocorra o preenchimento de algum deles, a prova se tornará frágil e imprestável para o cumprimento de seu objetivo. São eles: autenticidade, integridade e confiabilidade. O critério da autenticidade significa a "certeza com relação ao autor ou autores do fato digital". ${ }^{34}$ É a confiança de que aquela prova, apresenta, de fato, o seu autor real, ou seja, de quem participou da constituição do fato. Uma prova que não detém tal critério, é uma prova não autêntica, e que, portanto, não apresenta elementos de certeza e veracidade, o que como consequência, leva ao enfraquecimento da prova. ${ }^{35}$

É neste sentido que fora promulgada a Medida Provisória ํo 2.200 de 2001, que versou sobre implantação de Infraestrutura de Chaves Públicas, a ICP-Brasil. Com a adoção das Chaves Públicas, passou-se a exigir que os documentos transmitidos por este certificado digital, pudessem receber uma chancela do Estado, no intuito de garantir a terceiros a autenticidade do documento. Tal regramento se reproduziu no próprio CPC/15 pelos artigos 19, 29, 41, 195, 264, 267, 367, 411-412, 421-422, 425, 428-429, 439, 478, 522, 882, 914 e 965.

O uso da certificação digital “afastou significativamente a possibilidade de invasões ao sistema judicial eletrônico, tornando os próprios advogados e serventuários da justiça responsáveis pela portabilidade de seus certificados emitidos". ${ }^{36}$ Isto afastou possíveis fraudes, adulterações ou interceptações

34 THAMAY, Rennan; TAMER, Maurício. Provas no direito digital: conceito da prova digital: procedimentos e provas digitais em espécie. São Paulo: Thomson Reuters Brasil, 2020, p. 40.

35 THAMAY, Rennan; TAMER, Maurício. Provas no direito digital: conceito da prova digital: procedimentos e provas digitais em espécie. São Paulo: Thomson Reuters Brasil, 2020, p. 40.

36 NERY, Loschiavo Fernando. O documento eletrônico e sua eficácia como prova processual: desmistificando o preconceito a novas tecnologias. Revista Jurídica da Universidade do Sul de Santa Catarina. Unisul de Fato e de Direito. Ano IV, no 08 - Jan.-Jun. 2014, p. 256. 
de documentos eletrônicos, conferindo ainda mais segurança no processo e procedimento.

Quanto as formas de se atestar a autenticidade de um documento, esta poderá ocorrer por meio dos "fatores de autenticação, que por sua vez são subdivididas em algo 'que se TEM' (e-mails ou tokens), algo 'que se SABE' (senhas e dados pessoais) e algo 'que se É' (fatores biométricos)". ${ }^{37}$ É por meio da autenticidade que também é possível constatar se houver testemunhas, "seja pela autenticação de uma pessoa específica com aquela finalidade, seja pela indicação da testemunha principal no âmbito digital: a máquina (representada por MAC Adress, IPe registros similares)". 38

A segurança da autenticidade é utilizada tanto pelo setor público, mas, principalmente, pelo privado. No exercício da advocacia, em alguns sistemas de processo eletrônico como o PROJUDI, por exemplo, o advogado precisa autenticar as petições e documentos que for protocolar, por meio do assinador digital, que confere autenticidade e veracidade às provas colacionadas aos autos. E se a prova não tiver tal autenticação, ela será inválida? Veja-se que no caso de alegação de calúnia e difamação em uma página de mídias sociais, por exemplo, para se atestar a veracidade das informações, será necessária a quebra do sigilo da postagem, com o fornecimento judicial dos dados dos provedores, a fim de se comprovar a origem da postagem e, até mesmo, se não se trata de uma postagem fake, feita pelo próprio autor, com o intuito de prejudicar terceiro. ${ }^{39}$ Se não existir tal prova, certamente haverá dúvidas quanto a autoria do ato, o que ocasionará a inutilidade da prova obtida. Já quanto ao critério da integridade, por sua vez, trata-se da qualidade, integridade da prova digital, ou seja, aquela que não sofreu qualquer adulteração. A integridade consiste "na proteção do conjunto probatório contra alterações acidentais ou intencionais, conservando seu estado original na época da contratação realizada, sendo hábil para eventual perícia ou coleta de dados" . ${ }^{40}$

Alterações quando da transmissão de determinados dados, corrompendo o seu conteúdo, podem acontecer. Contudo, quando há uma ação humana intencional a isto, a integridade daquela prova se mostra comprometida, o que, como consequência, prejudica a sua utilização no processo. Exemplo de adulteração intencional de dados pode ocorrer quando uma das partes oculta determinada parte da conversa de WhatsApp, no intuito de induzir o juízo a erro. E é justamente para se evitar situações

37 PINHEIRO, Patrícia Peck; WEBER, Sandra Tomazi; OLIVEIRA NETO, Antônio Alves de. Fundamentos dos negócios e contratos digitais. [livro eletrônico]. São Paulo: Thomson Reuters Brasil, 2019.

38 PINHEIRO, Patrícia Peck; WEBER, Sandra Tomazi; OLIVEIRA NETO, Antônio Alves de. Fundamentos dos negócios e contratos digitais. [livro eletrônico]. São Paulo: Thomson Reuters Brasil, 2019.

39 THAMAY, Rennan; TAMER, Maurício. Provas no direito digital: conceito da prova digital: procedimentos e provas digitais em espécie. São Paulo: Thomson Reuters Brasil, 2020, p. 44.

40 PINHEIRO, Patrícia Peck; WEBER, Sandra Tomazi; OLIVEIRA NETO, Antônio Alves de. Fundamentos dos negócios e contratos digitais. [livro eletrônico]. São Paulo: Thomson Reuters Brasil, 2019. 
como estas, que se dá preferência a uma ata notarial com printscreen, ao invés de apresentações das telas pela parte, uma vez que facilmente se poderá adulterar. ${ }^{41}$

Não há como se negar que é bastante simples alterar uma conversa de aplicativo de mensagens, postagens em mídias sociais ou e-mails. Também não há como atestar, com total certeza, que a ata notarial esteja isenta de qualquer adulteração. Contudo, considerando a fé pública do tabelião no exercício de seu múnus público, este deve assegurar a integridade do ato. A coleta de uma prova digital deve demonstrar que o elemento probatório permanece inalterado. Isto é possível verificar por meio da clonagem de dispositivos de armazenamento, de modo que a análise de toda a prova seja feita no dispositivo clone, a fim de conservar o dispositivo mãe em sua integralidade. Ainda, para se dar ainda mais aparência de integralidade, recomenda-se que todo o procedimento seja acompanhado da lavratura de ata notarial. ${ }^{42}$

Outra forma de constatar a integralidade de uma prova, é por meio da extração do código Hash sobre a cópia realizada, atestando que esta é um espelho idêntico da original. Trata-se de um código alfanumérico que é gerado de forma única para o dispositivo clonado "pois sua sequência numérica é extraída apenas após a análise byte a byte comparativa" ou seja, "o código é extraído porque se comparam todas as partes de todos os arquivos de ambos os dispositivos (cópia e original), atestando a plena e completa identidade entre eles". ${ }^{43}$ Os tribunais já têm admitido a utilização deste código para se atestar a integralidade da prova. Em decisão proferida pelo Superior Tribunal de Justiça em dezembro de 2020 - REsp 1656348/SP -, se utilizou do código Hash para determinar uma tutela inibitória visando impedir o compartilhamento de determinado vídeo. ${ }^{44}$

41 THAMAY, Rennan; TAMER, Maurício. Provas no direito digital: conceito da prova digital: procedimentos e provas digitais em espécie. São Paulo: Thomson Reuters Brasil, 2020, p. 45.

42 THAMAY, Rennan; TAMER, Maurício. Provas no direito digital: conceito da prova digital: procedimentos e provas digitais em espécie. São Paulo: Thomson Reuters Brasil, 2020, p. 45.

43 THAMAY, Rennan; TAMER, Maurício. Provas no direito digital: conceito da prova digital: procedimentos e provas digitais em espécie. São Paulo: Thomson Reuters Brasil, 2020, p. 46.

44 RECURSOS ESPECIAIS. FACEBOOK E AMBEV. DIREITO CIVIL E PROCESSUAL CIVIL. AGRAVO DE INSTRUMENTO. AÇÃO DE OBRIGAÇÃO DE FAZER E NÃO FAZER. TUTELA ANTECIPADA. COMPARTILHAMENTO MEDIANTE O WHATSAPP DE VIIDEO EM QUE SE ENSINARIA A CONTRAFAÇÃO DE DETERMINADO PRODUTO. TUTELA INIBITÓRIA. PRETENSÃO DE APLICAÇÃO DE FILTRO TECNOLÓGICO NO APLICATIVO A VEDAR O COMPARTILHAMENTO DO VÍDEO COM BASE NO SEU "HASH". 1. Discussão acerca da reunião dos requisitos para o deferimento de tutela antecipada, determinando-se a abstenção de compartilhamento de vídeo pelo aplicativo de comunicação denominado WhatsApp em que se demonstraria o procedimento para a falsificação de garrafa de cerveja, substituindo-se o rótulo e a tampa de determinado produto pelo rótulo e tampa de cerveja fabricada pela recorrente. 2. Desistência do recurso especial do Facebook, remanescendo o recurso especial da Ambev. 3. Inocorrência de negativa de prestação jurisdicional, tendo sido devidamente analisadas as questões alegadas como omissas no recurso especial diante da fundamentação a compreender o cerne da controvérsia ao Tribunal de origem devolvida, não havendo falar em omissão do aresto. 4. Tempestividade do agravo de instrumento. A oposição de embargos de declaração, conhecidos e rejeitados, mesmo que possuam "caráter de reconsideração do pedido", como defende a recorrente, determina a incidência do natural efeito interruptivo. Precedentes desta Corte. 5. Vídeo compartilhado em que se estaria, a um só tempo, a violar a propriedade intelectual da recorrente, representada nas marcas cujo uso lhe é exclusivo, e a colocar 
Um outro método que pode ser utilizado, para fins de atestar a integralidade de determinada prova digital, é o registro do documento com cláusulas gerais da contratação no Registro de Títulos e Documentos - RTD. Contudo, tal registro não é obrigatório, e objetiva apenas garantir a publicidade do documento, e de que aquele era o texto redigido, no momento de sua contratação. ${ }^{45} 0$ terceiro critério que necessita estar presente, para a admissibilidade de uma prova digital, é a confiabilidade, também denominada de preservação a cadeia de custódia.

Tal critério está interligado à segurança de todo o fluxo de informações que se pretende realizar de forma eletrônica. Importante destacar que a "segurança da informação não diz respeito só a parâmetros técnicos de identificação, coleta, aquisição e preservação das provas eletrônicas", mas sim, “abrange toda a gestão dos ambientes de hardware e software que suportam a operação de contratação eletrônica, incluindo a confidencialidade das informações inerentes ao contrato eletrônico firmado". ${ }^{46}$

em risco a incolumidade da saúde dos consumidores em geral por demonstrar o “modus operandi” para a adulteração de garrafas de cerveja (tampa e rotulagem). 6 . Situação em análise que poderia ser ainda mais grave acaso os frascos estivessem vazios, podendo-se neles inserir toda a sorte de líquidos que, colocados à disposição da coletividade com a marca da autora, poderiam colocar em risco a saúde dos consumidores que viessem a ingeri-los e, ainda, a imagem da sociedade demandante. 7. Fase incipiente do processo a necessitar de uma mais aprofundada dilação probatória por se tratar de matéria especialmente técnica, evidenciando a possibilidade de suspender-se o compartilhamento do vídeo em questão, uma vez temporariamente hospedado em um servidor na "nuvem", e, ainda, identificado mediante a utilização de algoritmo a atribuir código "hash" ao arquivo. 8. Processo que, sinteticamente, parte da aplicação de um algoritmo sobre determinadas informações digitais (aí incluído arquivo de determinado vídeo) do qual é gerado um código chamado "hash" (uma sequência de letras e números) e que permite verificar a identidade e integridade do arquivo onde quer que esteja armazenado, inclusive backups. 9. Recurso especial interposto em face de decisão pautada em juízo de aparência. Impossibilidade de se avançar sobre as questões de fundo que ainda precisam ser examinadas sob cognição exauriente pela instância de origem. Enunciado 735/STF. 10. Necessidade de investigação acerca da probabilidade de uma eventual geração de códigos idênticos, alcançando-se outros vídeos que não aqueles em que praticado o ilícito, caso em que se poderia comprometer o direito de liberdade de expressão e comunicação dos usuários do WhatsApp. 11. Necessidade, ainda, de verificação da concreta possibilidade de se utilizar o "hash" do arquivo de vídeo indigitado (sistema comumente utilizado para comprovar a autenticidade e regularidade da cadeia de custódia material de provas coletadas em buscas e apreensões) para a identificação e bloqueio junto ao sistema adotado pelo WhatsApp, sob pena de prolatar-se decisão tecnicamente inexequível. 12. Ausência de elementos de convicção, também, acerca da viabilidade da aplicação da técnica de identificação do arquivo objeto de compartilhamento em face do sistema de encriptação adotado pelo aplicativo WhatsApp, denominado de criptografia de ponta a ponta, que, sabidamente, codifica automaticamente todas as mensagens quando enviadas pelo usuário e apenas as descodifica quando chegam ao destinatário, caso em que não se teria acesso ao seu conteúdo para, então, calcular o "hash" do arquivo que estaria sendo enviado. 13. Sobejando questões extremamente técnicas a serem respondidas por profissionais do específico campo da tecnologia da informação antes que o pedido de antecipação de tutela possa a ser, com segurança, analisado, é de rigor o desprovimento do recurso. 14. RECURSO ESPECIAL CONHECIDO E DESPROVIDO. (REsp 1656348/SP, Rel. Ministro PAULO DE TARSO SANSEVERINO, TERCEIRA TURMA, julgado em 01/12/2020, DJe 18/12/2020).

45 PINHEIRO, Patrícia Peck; WEBER, Sandra Tomazi; OLIVEIRA NETO, Antônio Alves de. Fundamentos dos negócios e contratos digitais. [livro eletrônico]. São Paulo: Thomson Reuters Brasil, 2019.

46 PINHEIRO, Patrícia Peck; WEBER, Sandra Tomazi; OLIVEIRA NETO, Antônio Alves de. Fundamentos dos negócios e contratos digitais. [livro eletrônico]. São Paulo: Thomson Reuters Brasil, 2019. 
(...) uma base computacional confiável (BCC) contém hardware e software além de vias de comunicação confiáveis (VCC) entre várias bases computacionais. Em termos leigos, os sistemas de informação são considerados confiáveis quando há proteção encapsulando os equipamentos físicos, os programas e os dados em determinada área de processamento e protegendo as transações entre usuários utilizando canais seguros. ${ }^{47}$

Ao analisar o critério de confiabilidade, trata-se de "construir um verdadeiro registro histórico de evidência, de toda a vida da prova. A ideia é que se alguém seguir os mesmos passos já dados na produção da prova, o resultado será exatamente o mesmo". ${ }^{48}$ Para tanto, é importante que sejam indicados os horários, datas, quem teve acesso, em qual local e, até mesmo, as alterações que foram realizadas no arquivo. Neste sentido, o art. 13 do Decreto no 8.771/2016, que regulamenta o Marco Civil da Internet, apresenta inúmeras providências quanto à segurança da informação e sua cadeia de custódia. ${ }^{49}$

Órgãos reguladores como o Banco Central do Brasil, por meio do sistema BACEN, ou ainda, a Superintendência de Seguros Privados (SUSEP), também se preocupam com a cadeia de custódia da prova digital, posto que "exigem que a contratação eletrônica não seja firmada apenas com o objetivo de fazer prova de autoria e integralidade em juízo, mas que se leve em consideração as premissas técnicas e jurídicas que tornarão a própria plataforma de contratação eletrônica idônea". 50

Se a prova digital possuir os critérios de autenticidade, integridade e confiabilidade, está apta a ser inserida dentro de um processo judicial. Obviamente que tais requisitos podem ser modificados com a evolução da tecnologia e das formas de verificação de determinado documento, mas não há como se negar que, quanto

47 LEWIS, Theodore Gyle. Critical infrastructure protection in homeland security. defending a networked nation. $2^{\mathrm{a}}$ ed. New Jersey: John Wiley \& Sons, 2015, p. 145.

48 THAMAY, Rennan; TAMER, Maurício. Provas no direito digital: conceito da prova digital: procedimentos e provas digitais em espécie. São Paulo: Thomson Reuters Brasil, 2020, p. 47.

49 Decreto 8.771/16 (Decreto do Marco Civil da Internet): “Art. 13. Os provedores de conexão e de aplicações devem, na guarda, armazenamento e tratamento de dados pessoais e comunicações privadas, observar as seguintes diretrizes sobre padrões de segurança: I- o estabelecimento de controle estrito sobre o acesso aos dados mediante a definição de responsabilidades das pessoas que terão possibilidade de acesso e de privilégios de acesso exclusivo para determinados usuários;

II - a previsão de mecanismos de autenticação de acesso aos registros, usando, por exemplo, sistemas de autenticação dupla para assegurar a individualização do responsável pelo tratamento dos registros; III- a criação de inventário detalhado dos acessos aos registros de conexão e de acesso a aplicações, contendo o momento, a duração, a identidade do funcionário ou do responsável pelo acesso designado pela empresa e o arquivo acessado, inclusive para cumprimento do disposto no art. 11, § 3o, da Lei 12.965, de 2014; e IV- o uso de soluções de gestão dos registros por meio de técnicas que garantam a inviolabilidade dos dados, como encriptação ou medidas de proteção equivalentes".

50 PINHEIRO, Patrícia Peck; WEBER, Sandra Tomazi; OLIVEIRA NETO, Antônio Alves de. Fundamentos dos negócios e contratos digitais. [livro eletrônico]. São Paulo: Thomson Reuters Brasil, 2019. 
mais critérios a prova produzir, maior será a sua robustez e, como consequência, a sua valoração, pelo magistrado, na prolação de sua decisão. Contudo, resta-nos verificar se, ao atingir tais requisitos, a prova digital é amplamente admitida no ordenamento jurídico brasileiro. É o que o próximo tópico, ponto principal do presente artigo, pretende abordar.

\section{Prova digital na prática jurídica e aspectos controvertidos no processo civil}

O texto segue apontando os principais aspectos da prova digital aplicadas no ordenamento jurídico brasileiro que na prática jurídica usual suscitam aprimoramento técnico principalmente por conta da utilização considerada controvertida em muitas situações. Repentinamente o uso de distintas tecnologias ganhou volume por conta das políticas de isolamento social causadas pela pandemia da Covid-19, quase todos os países, ambientes, áreas sofreram mudanças para se adaptar e manter o respeito ao contato mínimo. Logo as empresas mais que rapidamente adequaram seus procedimentos e rotinas ao sistema home office. Aquela forte resistência ao uso de tecnologia enfraqueceu e pode-se dizer que um grande avanço digital ocorreu, é inegável que a expansão do uso de recursos tecnológicos foi significativa. A publicidade apelou nas campanhas no discurso de que era a única maneira de a sociedade sobreviver e se manter economicamente a produção longe da crise, então, de forma remota muitos serviços adaptaram-se e até mesmo renderam lucros nos gastos de manutenção operacional.

Especialmente no Brasil, o governo federal editou a Medida Provisória no 2.200-2/2001, entre muitas alterações que ocorreram passou a ser garantida a validade e eficácia de documentos assinados digitalmente. Cresceu o uso de vistas por meio do uso de Chaves Públicas Brasileiras - ICP-Brasil. Neste sentido, destaca-se o art. 10, $\S^{\circ}{ }^{\circ}$ da Medida, que admite pleno uso do ambiente digital, utilização de documentos eletrônicos e softwares, inclusive os que se utilizam de outros certificados, flexibilizando a segurança antes garantida pelo ICP-Brasil. Qualquer certificado era válido, bastava que fosse feito acordo formal entre as partes que poderiam ser admitidos e totalmente válidos. ${ }^{51}$ Assim sendo são considerados elementos de autenticidade, integridade e confiabilidade do documento, contendo aqueles elementos indispensáveis para a admissão da prova no processo judicial.

Entretanto, a absoluta maioria das tratativas comerciais realizadas pela sociedade não estão chanceladas por qualquer certificado e não possuem órgão certificador, mesmo assim, precisam ser observadas pelo ordenamento jurídico e

51 Especialmente o item 13 da página referenciada: Instituto Nacional de Tecnologia da Informação. Disponível em: https://www.iti.gov.br/perguntas-frequentes/41-perguntas-frequentes/112-sobre-certificacao-digital. 
podem ser perfeitamente consideradas válidas. Com aperfeiçoamento da tecnologia, melhoramento dos meios de comunicação, padronização dos procedimentos e das tratativas comerciais digitais entre as partes também se modificaram de modo a atender as demandas e diminuir as barreiras para realização de comércio no ambiente eletrônico. Antes, o papel do contrato assinado, muitas vezes com firma reconhecida em cartório, era utilizado como prova. Sua ausência era caso do descumprimento contratual. Agora, são os contratos eletrônicos que balizam toda a relação comercial entre as partes podendo ser utilizados em qualquer tipo de acordo.

O movimento em prol da mudança já era demasiadamente acentuado, porém em muitos setores a resistência também permanecia grande. Mas a prática ganhou ainda mais força e a resistência (talvez por medo) foi liquidada especialmente após o surgimento da crise decorrente da pandemia da Covid-19, uma vez que as pessoas estavam impedidas do convívio social e, mesmo assim, necessitavam celebrar negócios jurídicos. Quase que inexplicável pela complexidade do fato vivenciado, mas sucintamente tudo ocorria simultaneamente com um conjunto inumerável de fatores pessimistas impulsionava todos para execuções práticas de consumo digitais. Assim, várias formas de comércio foram surgindo, somaram-se a flexibilização de regras modificando a prática das relações com facilidade para todos que optassem pela substituição.

De modo ilustrativo destaca-se o art. 784 do CPC/15 que nada dispõe acerca do documento digital ao tratar dos títulos executivos extrajudiciais, o que denota certo receio do legislador ao regulamentar esta espécie de tratativa comercial, fato que pode ser observado diversas vezes na Lei. Por exemplo, no que concerne ao documento particular, constante no inciso III do citado artigo. Consta a exigência de que o documento seja assinado pelas partes e também por duas testemunhas, é deste modo disposto e ainda permanece válido. Contudo, não é praticado no meio virtual tornando totalmente obsoleto e ineficaz, questiona-se: será que tais exigências ainda são necessárias? São praticadas em documentos digitais? Como tais requisitos devem ser preenchidos? Podem ser utilizados como prova? Caso o rol do art. 784 do CPC/15 é taxativo, pode-se afirmar que apenas as hipóteses ali citadas devem ser consideradas? parece que não. ${ }^{52}$ Ocorre que:

\footnotetext{
52 Nas palavras de Fredie Didier JR.: “A finalidade de o documento particular, para ser título executivo, contar com a assinatura de duas testemunhas, (...) é justamente convocá-las a testemunhar em juízo, caso o devedor alegue algum vício de vontade nos embargos à execução. Daí por que devem as testemunhas, no documento particular, ter presenciado sua elaboração e não estarem sujeitas às restrições legais relativas às testemunhas judiciais. Do contrário, ou seja, caso as testemunhas não desfrutem dessas qualidades, o documento particular não será título executivo extrajudicial, que somente poderá ser aferido, na hipótese de haver embargos à execução em que se alegue o vício e caso não haja prejuízo com tal defeito" (Curso de Direito processual Civil. V. 5. $7^{\mathfrak{a}}$ ed. Salvador: JusPodivm, 2016, p. 297-298).
} 
$\mathrm{Na}$ hipótese do inciso III do artigo supracitado, o legislador escolheu que o documento fosse assinado por duas testemunhas para conferir existência e validade ao negócio jurídico particular e, como consequência, afastar qualquer nulidade ao pacto, já que fora acompanhado por outras duas pessoas isentas, além das que participaram do negócio. Se tal validade puder ser expressa por outro meio, que não o testemunhal, é possível que tal requisito seja afastado, desde que seja possível verificar a validade do título por outros meios idôneos, como a assinatura do advogado de uma das partes, por exemplo, conforme entendimento do Superior Tribunal de Justiça no RESP 1.453.949/SP, de relatoria do Ministro Luís Felipe Salomão. ${ }^{53}$

Tal entendimento, posteriormente, ocasionou a recente interpretação do Superior Tribunal de Justiça - RESP 1.495.920/DF, de relatoria do Ministro Paulo de Tarso Sanseverino, ao consignar que a ausência da assinatura de testemunhas não afasta a executoriedade do título, sendo dispensado tal requisito formal para a execução de título eletrônico. Explica-se: o caso abordava o ajuizamento de uma execução de título

53 RECURSO ESPECIAL. EMBARgOS À EXECUÇÃO. Atributos do título. Confissão de dívida. Art. 580, Caput, do $\mathrm{CPC} / 1973$. Testemunha instrumentária. Advogado do exequente. Interesse no feito. Fato que não configura elemento capaz de macular a higidez do título executivo. Nulidade. Não ocorrência. 1. Apenas constituem títulos executivos extrajudiciais aqueles taxativamente definidos em lei, por força do princípio da tipicidade legal (nullus titulus sine legis), sendo requisito extrínseco à substantividade do próprio ato. 2. No tocante especificamente ao título executivo decorrente de documento particular, salvo as hipóteses previstas em lei, exige o normativo processual que o instrumento contenha a assinatura do devedor e de duas testemunhas (NCPC, art. 784, III, e CPC/73, art. 595, II), já tendo o STJ reconhecido que, na sua ausência, não há falar em executividade do título. 3. A assinatura das testemunhas é requisito extrínseco à substância do ato, cujo escopo é o de aferir a existência e a validade do negócio jurídico. O intuito foi o de permitir, quando aventada alguma nulidade do negócio, que as testemunhas pudessem ser ouvidas para certificar a existência ou não de vício na formação do instrumento, a ocorrência e a veracidade do ato, com isenção e sem preconceitos. 4. 'A assinatura das testemunhas instrumentárias somente expressa a regularidade formal do instrumento particular, mas não evidencia sua ciência acerca do conteúdo do negócio jurídico' (REsp 118.598-2/PE, Rel. Ministra Nancy Andrighi, Terceira Turma, j. 14.12.2010, DJe 02.02.2011). Em razão disso, a ausência de alguma testemunha ou a sua incapacidade, por si só, não ensejam a invalidade do contrato ou do documento, mas apenas a inviabilidade do título para fins de execução, pela ausência de formalidade exigida em lei. 5. Esta Corte, excepcionalmente, tem entendido que os pressupostos de existência e os de validade do contrato podem ser revelados por outros meios idôneos, e pelo próprio contexto dos autos, hipótese em que tal condição de eficácia executiva - a assinatura das testemunhas poderá ser suprida. 6. O Superior Tribunal de Justiça, em razão das disposições da lei civil a respeito da admissibilidade de testemunhas, tem desqualificado o título executivo quando tipificado em alguma das regras limitativas do ordenamento jurídico, notadamente em razão do interesse existente. A coerência de tal entendimento está no fato de que nada impede que a testemunha participante de um determinado contrato (testemunha instrumentária) venha a ser, posteriormente, convocada a depor sobre o que sabe a respeito do ato negocial em juízo (testemunha judicial). 7. Em princípio, como os advogados não possuem o desinteresse próprio da autêntica testemunha, sua assinatura não pode ser tida como apta a conferir a executividade do título extrajudicial. No entanto, a referida assinatura só irá macular a executividade do título, caso o executado aponte a falsidade do documento ou da declaração nele contida. 8. Na hipótese, não se aventou nenhum vício de consentimento ou falsidade documental apta a abalar o título, tendo-se, tão somente, arguido a circunstância de uma das testemunhas instrumentárias ser, também, o advogado do credor. 9. Recurso especial não provido" (REsp 1.453.949/SP, rel. Min. Luis Felipe Salomão, Quarta Turma, j. 13.06.2017, DJe 15.08.2017). 
extrajudicial proposta pela Fundação dos Economiários Federais - FUNCEF, que em primeira instância fora extinta, sem resolução do mérito, por ausência de requisito básico para a executoriedade do título - a assinatura de duas testemunhas, nos termos do art. 784, III, do CPC/15. A sentença permaneceu mantida pelo Tribunal de Justiça do Distrito Federal e Territórios, porque embora tenha se reconhecido a assinatura eletrônica das partes via certificado digital, entendeu que a simples assinatura das partes, por si só, “não produz a eficácia de um título executivo extrajudicial, pois ausente um requisito essencial do tipo aberto do inciso II do art. 585 do CPC, qual seja, a assinatura de duas testemunhas". ${ }^{54}$

Em razão da negativa de provimento, a FUNCEF interpôs Recurso Especial, sustentando que o contrato possuía todos os requisitos necessários, inclusive as duas formas de testemunhos - do ICP-Brasil, e o segundo no Comprova.com, ambos que confirmam a executoriedade do título. Em seu voto, o Min. Relator Paulo de Tarso Sanseverino, ao tratar do contrato eletrônico assinado digitalmente, consignou que "há de se ter tal instrumento de contratação como executivo, porque reiteradamente celebrado atualmente, e ainda, por corporificar obrigação de pagar líquida, certa e exigível e, especialmente, porque fazem as vezes das testemunhas a certificação pelo ICP e, ainda a utilização dos serviços do "Comprova.com". ${ }^{55}$

Contudo, em que pese as razões do Relator, o entendimento não fora unânime, tendo o Ministro Villas Boas Cueva discordado do posicionamento, ao exarar que

54 RECURSO ESPECIAL. Civil e processual civil. Execução de título extrajudicial. Executividade de contrato eletrônico de mútuo assinado digitalmente (criptografia assimétrica) em conformidade com a infraestrutura de chaves públicas brasileira. Taxatividade dos títulos executivos. Possibilidade, em face das peculiaridades da constituição do crédito, de ser excepcionado o disposto no art. 585, inciso II, do CPC/73 (art. 784, inciso III, do CPC/2015). Quando a existência e a higidez do negócio puderem ser verificadas de outras formas, que não mediante testemunhas, reconhecendo-se executividade ao contrato eletrônico. Precedentes. 1. Controvérsia acerca da condição de título executivo extrajudicial de contrato eletrônico de mútuo celebrado sem a assinatura de duas testemunhas. 2. O rol de títulos executivos extrajudiciais, previsto na legislação federal em "numerus clausus", deve ser interpretado restritivamente, em conformidade com a orientação tranquila da jurisprudência desta Corte Superior. 3. Possibilidade, no entanto, de excepcional reconhecimento da executividade de determinados títulos (contratos eletrônicos) quando atendidos especiais requisitos, em face da nova realidade comercial com o intenso intercâmbio de bens e serviços em sede virtual. 4. Nem o Código Civil, nem o Código de Processo Civil, inclusive o de 2015, mostraram-se permeáveis à realidade negocial vigente e, especialmente, à revolução tecnológica que tem sido vivida no que toca aos modernos meios de celebração de negócios, que deixaram de se servir unicamente do papel, passando a se consubstanciar em meio eletrônico. 5. A assinatura digital de contrato eletrônico tem a vocação de certificar, através de terceiro desinteressado (autoridade certificadora), que determinado usuário de certa assinatura a utilizara e, assim, está efetivamente a firmar o documento eletrônico e a garantir serem os mesmos os dados do documento assinado que estão a ser sigilosamente enviados. 6 . Em face destes novos instrumentos de verificação de autenticidade e presencialidade do contratante, possível o reconhecimento da executividade dos contratos eletrônicos. 7. Caso concreto em que o executado sequer fora citado para responder a execução, oportunidade em que poderá suscitar a defesa que entenda pertinente, inclusive acerca da regularidade formal do documento eletrônico, seja em exceção de pré-executividade, seja em sede de embargos à execução. 8. RECURSO ESPECIAL PROVIDO. (REsp 1.495.920/DF, rel. Min. Paulo de Tarso Sanseverino, Terceira Turma, j. 15.05.2018, DJe 07.06.2018).

55 STJ, REsp 1.495.920/DF, rel. Min. Paulo de Tarso Sanseverino, Terceira Turma, j. 15.05.2018, DJe 07.06.2018. 
“não há como atribuir ao contrato que instrui a inicial da execução a qualidade de título executivo extrajudicial sem extrapolar, em muito, os limites da legislação vigente", não sendo razoável atribuir à parte executada o ônus de comprovar a invalidade de um documento que "não preenche minimamente os requisitos legais para dar início a um gravoso processo de execução". Assim, a Terceira Turma do Superior Tribunal de Justiça entendeu que o contrato eletrônico de mútuo, sem a assinatura de duas testemunhas, deve ser reconhecido como título extrajudicial. Ao analisar o julgado, é importante se fazer uma ressalva: e se o contrato não houvesse sido assinado via certificado digital ICP-Brasil, mas tão somente, por mero aceite digital, o resultado seria o mesmo? Com base nos argumentos esposados pelo Relator, parece que não. Um dos argumentos esposados pelo Ministro é o de que "a assinatura digital realizada no instrumento contratual eletrônico mediante chave pública (...) tem a vocação de certificar - através de terceiro desinteressado (autoridade certificadora) - que determinado usuário de certa assinatura digital privada a utilizara e, assim, está efetivamente a firmar o documento eletrônico e a garantir serem os mesmos os dados do documento assinado que estão a ser enviados". ${ }^{56}$ Portanto, a admissibilidade de contratos eletrônicos mediante assinatura por simples aceite digital, ou seja, sem o aceite de qualquer agente certificadora, é questão que ainda deverá ser enfrentada pelos Tribunais Superiores.

Portanto, em que pese o art. 784 do CPC/15 não tenha alterado a previsão de codificação dos títulos extrajudiciais, a decisão conferida pelo Superior Tribunal de Justiça no REsp 1.495.920/DF se mostra correta e adequada aos avanços tecnológicos da sociedade. Contudo, é importante ressaltar que o caso não fora decidido em sede de recurso repetitivo e, portanto, não possui efeito vinculante, o que poderá causar entraves extremamente formalistas pelas instâncias inferiores. Outra análise, a facilidade na utilização das plataformas de conversas instantâneas

56 "Deste todo interpretativo, tem-se a concluir que, em regra, exige-se as testemunhas em documento físico privado para que seja considerado executivo, mas excepcionalmente, poderá ele dar azo a um processo de execução, sem que se tenha cumprido o requisito formal estabelecido no art. 585, II, do CPC/73, qual seja, a presença de duas testemunhas, entendimento este que estou em aplicar aos contratos eletrônicos, desde que observadas as garantias mínimas acerca de sua autenticidade e segurança. 0 contrato eletrônico, em face de suas particularidades, por regra, tendo em conta a sua celebração à distância e eletronicamente, não trará a indicação de testemunhas, o que, entendo, não afasta a sua executividade. (...) Acerca dos requisitos do contrato eletrônico, ou para que sejam utilizados como prova, Patrícia Peck lembra exigirem: 'a certificação eletrônica, assinatura digital, autenticação eletrônica, para manter a autenticidade e integridade do documento, conforme o meio que foi utilizado para a sua realização.' Pela conformação dos contratos eletrônicos, o estabelecimento da necessidade de conterem a assinatura de 2 testemunhas para que sejam considerados executivos, dificultaria, por deveras, a sua satisfação. Se, como ressalta a referida doutrinadora, agrega-se a eles autenticidade e integridade mediante a certificação eletrônica, utilizando-se a assinatura digital devidamente aferida por autoridade certificadora legalmente constituída, parece-me mesmo desnecessária a assinatura das testemunhas. (...) Ainda assim, em face destes novos instrumentos de verificação de autenticidade e presencialidade do contratante e adequação do conteúdo do contrato, penso ser o momento de reconhecer-se a executividade dos contratos eletrônicos. (...) Ante o exposto, dou provimento ao recurso especial, determinando o prosseguimento do processo executivo. (...)". 
como WhatsApp, Telegran e Instagram é um dos atributos que motiva ainda mais pessoas a aderirem a estes recursos tecnológicos. E é justamente pela flexibilidade e adaptabilidade de tais aplicativos às mais diversas idades, é que o fluxo de informações trocadas por este meio é bastante diversificado, pois abrange desde conversas triviais, organizações de reuniões, gerenciamento de tarefas, até a celebração de contratos de prestação de serviços.

Visando atribuir maior segurança aos seus usuários, o aplicativo WhatsApp garante aos seus usuários o sigilo das conversas que ali são trocadas, por meio da utilização da criptografia de "ponta-a-ponta”. Em que pese tal sistema de segurança tenha como intuito impedir que terceiros tenham acesso às suas conversas, por outro lado, tal interface não impede que pessoas invadam a sua conta e tenham acesso às suas informações. A fluidez da utilização desses aplicativos remete, por outro lado, à preservação de privacidade das informações ali trocadas. Ou seja, “as mesmas razões que justificam o sigilo dos referidos meios se prestam à proteção da referida forma de comunicação, o que leva à conclusão de que o conteúdo das mensagens só pode ser acessado mediante prévia ordem judicial". ${ }^{57}$

As conversas de aplicativos de mensagens já são usadas como evidências em processos judiciais, desde o pedido de pagamento de pensão alimentícia, demissão por justa causa, direito do consumidor, prestação de serviços, até as tratativas de um contrato de prestação de serviços, pactuado por este meio. Mas assim como tais aplicativos se mostram ferramentas que facilitam a comunicação entre as partes, por outro lado, também são fáceis de serem manipuladas ou falseadas, seja com a inclusão ou omissão de parte de uma conversa, por exemplo. E é neste aspecto que a utilização das informações trocadas nestes aplicativos, como prova em um processo judicial, merece algumas observações.

O Poder Judiciário, de um modo geral, já tem admitido a utilização de printscreen de conversas, em aplicativos de mensagens, como prova. Todavia, em alguns casos, a sua utilização se apresenta ilícita e, como consequência, a prova se torna imprestável. É o que ocorreu no RHC no 99735/SC, que tramitou perante a Sexta Turma do Superior Tribunal de Justiça, de relatoria da Min. Laurita Vaz, em que o Superior Tribunal de Justiça considerou ilícito o espelhamento do WhatsApp do investigado, sem a sua ciência, via QR CODE por meio do site WhatsApp Web, sob o fundamento de que no espelhamento de mensagens, o interceptador deixa de ser mero observador, sendo possível a sua interferência direta no conteúdo, apagando ou enviando mensagens, sem o consentimento da parte. ${ }^{58}$

57 DIDIER JR., Fredie; BRAGA, Paula Sarno; OLIVEIRA, Rafael Alexandria de. Curso de direito processual civil: teoria da prova, direito probatório, decisão, precedente, coisa julgada, processo estrutural e tutela provisória. 15a ed. Salvador: JusPodivm, 2020, p. 127.

58 “WHATSAPP WEB. Autorização judicial de espelhamento. Conversas realizadas pelo investigado com terceiros. Instituto da interceptação telefônica. Analogia. Impossibilidade. Inicialmente, cumpre salientar 
O printscreen das mensagens de aplicativos trocados entre as partes, desde que um deles seja o participante da conversa, também tem sido aceito pelo Poder Judiciário. Não é exigido que tais informações sejam registradas por meio de ata notarial, exceto se a parte adversa alegar manipulação ou omissão de informações. Tal prova digital é bastante utilizada para se comprovar o descumprimento de determinado contrato, alienação parental, danos materiais, morais e tratativas entre as partes, especialmente no âmbito dos Juizados Especiais, em razão da informalidade do sistema e, da dispensa de advogado nas causas até vinte salários mínimos. Inclusive, o próprio Poder Judiciário tem se utilizado de tal meio para diversos fins. É o que se verifica no Al no 0056285-94.2020.8.16.0000, que tramitou perante a 6a Câmara Cível do Tribunal de Justiça do Paraná, de relatoria do Des. Renato Lopes de Paiva, em que houve o indeferimento do benefício da assistência judiciária gratuita à parte com base em conversas de aplicativo anexadas pelo próprio requerente, em que se demonstrou que a parte detinha condições de arcar com os custos processuais, pois era profissional de arquitetura, mestrando e professor de ensino da língua inglesa. ${ }^{59}$

que, ao contrário da interceptação telefônica, no âmbito da qual o investigador de polícia atua como mero observador de conversas empreendidas por terceiros, no espelhamento via WhatsApp Web o investigador de polícia tem a concreta possibilidade de atuar como participante tanto das conversas que vêm a ser realizadas quanto das conversas que já estão registradas no aparelho celular, haja vista ter o poder, conferido pela própria plataforma online, de interagir diretamente com conversas que estão sendo travadas, de enviar novas mensagens a qualquer contato presente no celular, e de excluir, com total liberdade, e sem deixar vestígios, qualquer mensagem passada, presente ou futura. Insta registrar que, por mais que os atos praticados por servidores públicos gozem de presunção de legitimidade, doutrina e jurisprudência reconhecem que se trata de presunção relativa, que pode ser ilidida por contra-prova apresentada pelo particular. Não é o caso, todavia, do espelhamento: o fato de eventual exclusão de mensagens enviadas (na modalidade "Apagar para mim") ou recebidas (em qualquer caso) não deixar absolutamente nenhum vestígio nem para o usuário nem para o destinatário, e o fato de tais mensagens excluídas, em razão da criptografia end-to-end, não ficarem armazenadas em nenhum servidor, constituem fundamentos suficientes para a conclusão de que a admissão de tal meio de obtenção de prova implicaria indevida presunção absoluta da legitimidade dos atos dos investigadores, dado que exigir contraposição idônea por parte do investigado seria equivalente a demandar-Ihe produção de prova diabólica (o que não ocorre em caso de interceptação telefônica, na qual se oportuniza a realização de perícia). Em segundo lugar, ao contrário da interceptação telefônica, que tem como objeto a escuta de conversas realizadas apenas depois da autorização judicial (ex nunc), o espelhamento via QR CODE viabiliza ao investigador de polícia acesso amplo e irrestrito a toda e qualquer comunicação realizada antes da mencionada autorização, operando efeitos retroativos (ex tunc). Em termos técnico-jurídicos, o espelhamento seria melhor qualificado como um tipo híbrido de obtenção de prova consistente, a um só tempo, em interceptação telefônica (quanto às conversas ex nunc) e em quebra de sigilo de e-mail (quanto às conversas ex tunc). Não há, todavia, ao menos por agora, previsão legal de um tal meio de obtenção de prova híbrido. Por fim, ao contrário da interceptação telefônica, que é operacionalizada sem a necessidade simultânea de busca pessoal ou domiciliar para apreensão de aparelho telefônico, o espelhamento via QR CODE depende da abordagem do indivíduo ou do vasculhamento de sua residência, com apreensão de seu aparelho telefônico por breve período de tempo e posterior devolução desacompanhada de qualquer menção, por parte da autoridade policial, à realização da medida constritiva, ou mesmo, porventura acompanhada de afirmação falsa de que nada foi feito" (RHC 99.735-SC, Rel. Min. Laurita Vaz, por unanimidade, julgado em 27/11/2018, DJe 12/12/2018).

59 "Direito civil e constitucional. Agravo de instrumento contra decisão interlocutória que indeferiu o pedido de assistência judiciária gratuita. Pretensão de reforma. Requerente que, devidamente intimado, não comprova a insuficiência de recursos alegada - apesar de narrar a juntada de cópia de carteira de trabalho, bem como de extratos bancários, documentos que permitiram melhor elucidar seus ganhos, deixa de efetivamente 
As funcionalidades do aplicativo WhatsApp também passaram a ser utilizadas pelo Poder Judiciário para a intimação das partes, no âmbito dos Juizados Especiais. A implantação começou a ser realizada pelo Conselho Nacional de Justiça no ano de 2017 em todo o país, e é um reflexo da Lei no 11.419/2006, que trata da informatização do processo judicial pela tecnologia. No Estado do Paraná, o sistema foi instituído em setembro de 2017, pela Instrução Normativa Conjunta 01/2017, da 2º Vice-presidência do Tribunal de Justiça do Estado do Paraná, com a anuência do Corregedor-Geral de Justiça. Por meio desta ferramenta, a parte que assim desejar, poderá anuir com a intimação dos atos processuais via aplicativo. Para tanto, a parte deve assinar um termo de cadastro, aceite e comprometimento, fornecido pelo próprio Juizado Especial. Contudo, em que pese o procedimento pareça, à primeira vista, simples, a sua adoção necessita de algumas observações.

A primeira questão que se deve analisar é: e se houver o bloqueio do WhatsApp por determinação judicial, em razão do descumprimento de determinada norma, como ficam as intimações a estes usuários? Como controlar que a parte, de fato, teve ciência da intimação realizada? E se o seu aplicativo de mensagens vier a ser clonado, como o usuário e, o próprio cartório, deverão proceder? Nos casos em que a parte alega não ter recebido a intimação acerca da designação da audiência, o Tribunal de Justiça do Estado do Paraná, no Recurso Inominado no 0002184-98.2018.8.16.0058, de relatoria da Juíza Thais Ribeiro Franco Endo, se posicionou pela validade do ato processual, ao consignar que "pela juntada do Termo de Autorização para Intimação por WhatsApp, colacionado ao mov. 77.1, p. 2, que o Recorrente, aquiesceu com essa modalidade de intimação dos atos processuais, declarando expressamente possuir o aplicativo instalado no celular, além de outras informações necessárias à evitar nulidades processuais". ${ }^{60}$ Como fundamentação, a Juíza exarou que a mera indicação de entrega da mensagem já é suficiente para a realização da intimação da parte, bem como, que a comunicação do ato processual, via aplicativo de mensagens, resta configurada por dois requisitos: “1) a aquiescência da parte com esta modalidade de comunicação; e 2) a lavratura de certidão que confirma a entrega da intimação via WhatsApp, ainda que a leitura não tenha se perfectibilizado". ${ }^{61}$

colacionar tais elementos de prova - ante a omissão, informação que deve prevalecer é a acostada em conversa de "WhatsApp" trazida pelo próprio requerente aos autos, no sentido de que este possui dois empregos, sendo que, não tendo esclarecido sua renda, daí se deflui que ostenta montante suficiente para fazer frente às custas e despesas processuais. Recurso conhecido e não provido" (TJPR - 6a C. Cível 0056285-94.2020.8.16.0000 - Arapongas - Rel.: Desembargador Renato Lopes de Paiva - J. 09.02.2021).

60 TJPR - 4a Turma Recursal - 0002184-98.2018.8.16.0058 - Campo Mourão - Rel.: Thaís Ribeiro Franco Endo - J. 16.11.2020.

61 TJPR - 4a Turma Recursal - 0002184-98.2018.8.16.0058 - Campo Mourão - Rel.: Thaís Ribeiro Franco Endo - J. 16.11.2020. 
Tal entendimento também é adotado para além do âmbito dos Juizados Especiais, como nas ações de família, por exemplo. No Agravo de Instrumento no 033150-53.2020.8.16.0000, da 11aㅡ Câmara Cível, de relatoria do Desembargador Ruy Muggiati, a parte teria sido citada por hora certa e, posteriormente, contatada pelo aplicativo de WhatsApp, teria deixado de fornecer o seu endereço. Neste caso, o Tribunal conferiu legalidade ao contato com a parte via aplicativo de mensagens do WhatsApp, afastando a alegação de nulidade processual. ${ }^{62}$

Outro caso que demonstra os aspectos controvertidos da utilização das conversas de aplicativos como prova, foi o posicionamento do Superior Tribunal de Justiça no Recurso em Mandado de Segurança no 48.665-SP, da Segunda Turma, de relatoria do Min. Og Fernandes, em que se entendeu como lícita a prova obtida por meio de monitoramento de e-mail corporativo de servidor público, considerando, para tanto, que "as informações obtidas por monitoramento de e-mail corporativo de servidor público não configuram prova ilícita quando atinentes a aspectos não pessoais e de interesse da Administração Pública e da própria coletividade, sobretudo quando exista, nas disposições normativas acerca do seu uso, expressa menção da sua destinação somente para assuntos e matérias afetas ao serviço, bem como advertência sobre monitoramento e acesso ao conteúdo das comunicações dos usuários para cumprir disposições legais ou instruir procedimento administrativo". ${ }^{63}$

O Superior Tribunal entendeu pela mitigação do direito à intimidade em prol de um aspecto mais importante: a impossibilidade de se acobertar condutas ilícitas. Todos os casos até aqui apresentados, demonstram que ainda há aspectos controvertidos na utilização da prova digital, os quais necessitam ser analisados caso a caso. Talvez o ponto chave das divergências no modo de admissibilidade das provas digitais resida no fato de que enquanto uma prova física é difícil de ser

62 TJPR - 11ํㅗ C. Cível - 0033150-53.2020.8.16.0000 - Fazenda Rio Grande - Rel.: Desembargador Ruy Muggiati - J. 23.11.2020.

63 “DIREITO ADMINISTRATIVO. MONITORAMENTO DE E-MAIL CORPORATIVO DE SERVIDOR PÚBLICO. As informações obtidas por monitoramento de e-mail corporativo de servidor público não configuram prova ilícita quando atinentes a aspectos não pessoais e de interesse da Administração Pública e da própria coletividade, sobretudo quando exista, nas disposições normativas acerca do seu uso, expressa menção da sua destinação somente para assuntos e matérias afetas ao serviço, bem como advertência sobre monitoramento e acesso ao conteúdo das comunicações dos usuários para cumprir disposições legais ou instruir procedimento administrativo. No que diz respeito à quebra do sigilo das comunicações telemáticas, saliente-se que os dados são objeto de proteção jurídica. A quebra do sigilo de dados telemáticos é vista como medida extrema, pois restritiva de direitos consagrados no art. 5o, X e XII, da CF e nos arts. 11 e 21 do CC. Não obstante, a intimidade e a privacidade das pessoas, protegidas no que diz respeito aos dados já transmitidos, não constituem direitos absolutos, podendo sofrer restrições, assim como quaisquer outros direitos fundamentais, os quais, embora formalmente ilimitados - isto é, desprovidos de reserva -, podem ser restringidos caso isso se revele imprescindível à garantia de outros direitos constitucionais. No caso, não há de se falar em indevida violação de dados telemáticos, tendo em vista o uso de e-mail corporativo para cometimento de ilícitos. A reserva da intimidade, no âmbito laboral, público ou privado, limita-se às informações familiares, da vida privada, política, religiosa e sindical, não servindo para acobertar ilícitos. Ressalte-se que, no âmbito do TST, a temática já foi inúmeras vezes enfrentada" (TST, RR 613/2000-01310-0, DJe 10/6/2005). RMS 48.665-SP, Rel. Min. Og Fernandes, julgado em 15/9/2015, DJe 5/2/2016). 
alterada e, caso assim o fosse, seria perceptível a sua falsificação, a prova digital, por sua vez, é como uma prova "registrada na areia da praia" a qual, por sua vez, "é muito vulnerável, apagando-se com facilidade, sem deixar vestígios". ${ }^{64}$

Contudo, mesmo diante dos desafios trazidos pela prova digital, faz-se necessário avançar em seu estudo, e para tanto, impõe-se "a presença do legislador, disciplinando de forma minuciosa o valor que se pode dar aos documentos eletrônicos", bem como a forma como devem ser admitidos em um processo judicial. Não há como ignorar a realidade que se apresenta: os documentos físicos serão cada vez menos usuais, sendo substituídos, pouco a pouco, pelos digitais. Isto já acontece com a Carteira de Habilitação e do Trabalho digitais, com os cartões de crédito virtuais e documentos eletrônicos. E todos estes documentos, como consequência, serão utilizados como provas digitais em um processo judicial.

\section{Considerações finais}

Assim como a tecnologia e as formas de comunicação têm evoluído gradativamente, a sociedade e, como consequência, as formas de comprovar e julgar o direito também devem acompanhar o desenvolvimento do campo tecnológico, principalmente a prova digital. De modo inicial, as provas documentais trazidas aos autos de um processo judicial eram eminentemente físicas, atualmente, são as provas digitais que preenchem os autos, agora eletrônicos, dos processos judiciais, desde a juntada de contrato eletrônicos, printscreen de conversas em aplicativos, até a indicação de vídeos e áudios, tudo no intuito de promover um acesso amplo à parte, quanto à comprovação de sua causa de pedir e dos seus pedidos.

Os documentos eletrônicos se prestam à mesma finalidade que os físicos, qual seja: a comprovação dos fatos e de um pretenso direito; é necessário que se criem mecanismos para a admissibilidade da prova digital perante o ordenamento jurídico brasileiro. E os critérios de autenticidade, integridade e confiabilidade parecem ser um início para a construção e validade da prova digital dentro do processo judicial. Não há dúvidas de que, quanto mais preenchidos forem os critérios de admissibilidade, maior será a segurança jurídica para utilização da prova e, como consequência, a valoração daquela prova no julgamento da causa. Contudo, porque ainda persiste controvérsia em sua utilização, na prática, no ordenamento jurídico brasileiro?

Apesar das vozes eloquentes de que a "tecnologia é o futuro", e que os “avanços tecnológicos vieram para contribuir em uma sociedade igualitária”, o que se vê, no dia a dia da sociedade brasileira, é que uma parcela considerável da população ainda não possui acesso à internet e nem, tampouco, a meios para

${ }_{64}$ MARINONI, Luiz Guilherme; ARENHART, Sérgio Cruz. Prova e Convicção. 5a ed., rev., atual. e ampl. São Paulo: Revista dos Tribunais, 2019, p. 655. 
o seu uso, como computadores e smartphones. Tal realidade se apresentou de forma transparente na chegada da pandemia da Covid-19, em que milhares de alunos da rede pública não tiveram acesso às aulas remotas por não possuírem os requisitos tecnológicos básicos para tanto. Mas este cenário não é exclusivo da classe mais hipossuficiente. Veja-se que o sistema PROJUDI/PR passou a possibilitar a juntada de arquivos de áudio e vídeo pelas partes e advogados apenas no ano de 2020. Ou seja, se mesmo o Judiciário encontra dificuldades na atualização de seus próprios sistemas, quem dirá a população no geral, em sua grande parcela, indivíduos desprovidos dos meios tecnológicos básicos, como uma internet com velocidade adequada, para o acompanhamento de aulas remotas, em plena pandemia da Covid-19.

A utilização da prova digital no ordenamento jurídico brasileiro, portanto, além de necessitar de um maior cuidado por parte do legislador, na outra ponta, também deve ser oportunizada pelo Estado, com o fornecimento de internet a baixo custo para a população mais hipossuficiente, bem como a disponibilização de meios para a coleta destas provas. Como haverá a evolução da prova digital se os detentores dela - os cidadãos - não possuem ferramentas para a sua extração?

As decisões abordadas no presente artigo não pretendem esgotar o tema, mas sim, trazer uma reflexão de que, a cada dia, a prova digital tomará o espaço da prova física, e que se existem controvérsias acerca da sua admissibilidade, é necessário estudo, inclusão social e uma abordagem mais "destemida” do legislador e do próprio julgador, no que concerne à sua utilidade válida e prática no processo.

\section{Referências}

AMARAL, Paulo Osternack. Provas: atipicidade, liberdade e instrumentalidade. $2^{\mathrm{a}}$ ed. São Paulo: Revista dos Tribunais, 2015.

BONIZZI, Marcelo José Magalhães. Fundamentos da prova civil. São Paulo: Revista dos Tribunais, 2017.

CÂMARA, Alexandre Freitas. O novo processo civil brasileiro. 2ª ed. São Paulo: Atlas, 2016.

CAPONI, Remo. O princípio da proporcionalidade na justiça civil: primeiras notas sistemáticas. Tradução: Sérgio Cruz Arenhart. Revista de Processo, São Paulo: RT, v. 192, a. 36, p. 400-401, fev. 2011.

CARNELUTTI, Francesco. Diritto e processo. Napoli: Morano, 1958.

DINAMARCO, Cândido Rangel. Instituições de direito processual civil. 3a ed. São Paulo: Malheiros, 2003.

DIDIER Jr., Fredie; BRAGA, Paula Sarno. Carta psicografada como fonte de prova no processo civil. Revista de Pós-Graduação da Universidade da Bahia, 2013.

DIDIER JR., Fredie; BRAGA, Paula Sarno; OLIVEIRA, Rafael Alexandria de. Curso de direito processual civil: teoria da prova, direito probatório, decisão, precedente, coisa julgada e tutela provisória. 10aㅡ ed. Salvador: Juspodivm, 2015. 
GRECO, Leonardo. A reforma do direito probatório no processo civil brasileiro. Revista de Processo. São Paulo: RT, n. 240. 2015.

HAACK, Susan. Evidence matters: science, proof, and truth in the law. Cambridge: Cambridge University Press, 2014.

LESSA, Breno Munici. A invalidade das provas digitais no processo judiciário. 03 mar. 2010. Disponível em: http://jus.uol.com.br/revista/texto/14555/a-invalidade-das-provas-digitais-noprocesso-judiciario/print. Acesso em: 28 fev. 2021.

LEWIS, Theodore Gyle. Critical infrastructure protection in homeland security. defending a networked nation. $2^{\mathrm{a}}$ ed. New Jersey: John Wiley \& Sons, 2015.

LUDWIG, Guilherme Guimarães. Entre o Acesso à Justiça e a "Dependência Química" do Judiciário: a Conciliação Prévia como Resgate da Cidadania. RDC n. 71, Maio/Jun. 2011 - Assunto especial: Doutrina. Disponivel em: http://docplayer.com.br/8474151-Entre-o-acesso-a-justica-ea-ependencia-quimica-do-judiciario-a-conciliacao-previa-moresgate-da-idadania.html. Acesso em: 08 jun. 2020.

MARINONI, Luiz Guilherme; ARENHART, Sérgio Cruz; MITIDIERO, Daniel. Novo CPC/15 comentado. São Paulo: Revista dos Tribunais, 2015.

MARINONI, Luiz Guilherme; ARENHART, Sergio Cruz; MITIDIERO, Daniel. Novo curso de processo civil: tutela dos direitos mediante procedimento comum. V. 2. São Paulo: Revista dos Tribunais, 2015.

MARINONI, Luiz Guilherme; ARENHART, Sérgio Cruz. Prova e Convicção. 5a ed. São Paulo: Revista dos Tribunais, 2019.

MENDES, A. G. C. $O$ anteprojeto de código brasileiro de processos coletivos: visão geral e pontos sensíveis. In: GRINOVER, A. P.; MENDES, A. G. C.; WATANABE, K. Direito processual coletivo e o anteprojeto de Código Brasileiro de Processos Coletivos. São Paulo: Revista dos Tribunais, 2007.

MICHAELIS. Moderno Dicionário da Língua Portuguesa. Verbete: Prova. Disponível em: https:// michaelis.uol.com.br/moderno-portugues/busca/portugues-brasileiro/prova/ Acesso em: 30 set. 2019.

MOREIRA, José Carlos Barbosa. A garantia do contraditório na atividade de instrução. Revista de Processo, São Paulo, v. 35, p. 283, 1984.

MOREIRA, José Carlos Barbosa. Provas atípicas. Revisa de Processo, São Paulo: RT, v. 19, n. 76, 1994.

MOREIRA, José Carlos Barbosa. Alguns problemas atuais da prova civil. In: WAMBIER, Luiz Rodrigues; WAMBIER, Tereza Arruda Alvim (Org.). Atividade Probatória. São Paulo: Revista dos Tribunais, 2011. (Coleção doutrinas essenciais: Processo Civil. v. 4).

NERY, Loschiavo Fernando. O documento eletrônico e sua eficácia como prova processual: desmistificando o preconceito a novas tecnologias. Revista Jurídica da Universidade do Sul de Santa Catarina. Unisul de Fato e de Direito. a. 4, n. 8, jan./jun. 2014.

NOVO AURÉlIO SÉCULO XXI: LÍNGUA PORTUGUESA. Verbete Prova. Curitiba: Positivo, 2020.

RAFFUL, Leonardo José; RAFFUL, Ana Cristina. Prova eletrônica. Revista do Direito Público, Londrina, v. 12 , n. 2, p. 48-76, ago. 2017.

RIGHI, Ivan. Eficácia probatória do comportamento das partes. Revista da Faculdade de Direito da Universidade Federal do Paraná. Curitiba, n. 20, 1981/1982. Disponível em: https://revistas. ufpr.br/direito/article/view/8855/6165 Acesso em: 20 jun. 2020. 
SCHIER, Paulo Ricardo. A Constitucionalização do direito no contexto da Constituição de 1988. In: CLĖVE, Clèmerson Merlin (Org.). Direito Constitucional Brasileiro. São Paulo: Revista dos Tribunais, 2014.

TARUFFO, Michele. La prueba de los hechos. Madrid: Trotta, 2002.

TARUFFO, Michele. Prove atipiche e convincimento del giudice. Rivista di Diritto Processuale, Padova, a. 28, n. 3, p. 389-395, jul./set. 1973.

TARUFFO, Michele. A prova. Tradução: João Gabriel Couto. São Paulo: Marcial Pons, 2014.

TARUFFO, Michele. Abuso de direitos processuais: padrões comparativos de lealdade processual (relatório geral). Revista de Processo, São Paulo: RT, n. 177, a. 33, nov. 2009.

THAMAY, Rennan; TAMER, Maurício. Provas no direito digital: conceito da prova digital: procedimentos e provas digitais em espécie. São Paulo: Thomson Reuters, 2020.

THEODORO JUNIOR, Humberto. Curso de direito processual civil. São Paulo: Forense, 2015. v. 1.

VERDE, Giovanni. La prova nel processo civile (Profili di teoria generale). Rivista di Diritto Processuale. Padova: CEDAM, 1998.

WAMBIER, Luiz Rodrigues; TALAMINI, Eduardo. Curso avançado de processo civil. V. 2: Cognição jurisdicional: processo comum de conhecimento e tutela provisória. 16르 ed. São Paulo: Revista dos Tribunais, 2016.

Informação bibliográfica deste texto, conforme a NBR 6023:2018 da Associação Brasileira de Normas Técnicas (ABNT):

BERBERI, Marco Antonio Lima; HANTHORNE, Bruna de Oliveira Cordeiro. Aspectos controvertidos no uso da prova digital no ordenamento jurídico brasileiro. International Journal of Digital Law, Belo Horizonte, ano 2, n. 2, p. 137-165, maio/ago. 2021. 